\title{
Pengaruh kupas baik mahasiswa terhadap penerapan pelayanan Islami pada pasien rawat inap
}

\author{
Nurjanna, Wilda Rezki Pratiwi \\ Program Studi DIII Kebidanan STIKES Muhammadiyah Sidrap.`Email: wildapratiwi06@gmail.com \\ Abstract \\ The student's kupas baik in application of Islamic services among hospitalized patients
}

Background: Kupas baik is a program of activities carried out by the Office of International Affairs, Cooperation and Development of Al-Islam \& Kemuhammadiyahan which is one of the implementations of Muhammadiyah's higher education goals, namely the establishment of Islam and the Muhammadiyah. This educates and enlightens all academicians.

Purpose: To analyze the effect of Kupas baik Lecture Program in application of Islamic services among hospitalized patients

Method: A pre-experimental research method with a one-shot case study design. The study population was 105 people and sample amounted to 93 respondent by purposive sampling technique. The research instrument used a questionnaire. The data analysis technique uses One-Way Anova.

Results: The calculated $F$ value of 35.76 and the $F$ table value is 3.10 so that the calculated $F$ value $<F$ table (35.76 $<3.10)$ means that there is a good linear effect on Islamic services.

Conclusion: It is expected that the application of an Islamic service model as an alternative for treatment of patients as well as providing medical care and nursing is framed by Islamic principles with holistic approaches in the form of biopsico-social-cultural and spiritual services

\section{Keywords: Student; Kupas baik; Application; Islamic services; Hospitalized; Patients}

Pendahuluan: Kegiatan Kuliah Pas Sepuluh Menit Belajar Al- Islam dan Kemuhammadiyahan (KUPAS BAIK) adalah program kegaiatan yang dilakukan oleh Kantor Urusan Internasional, Kerjasama dan Pengembangan AlIslam \& Kemuhammadiyahan yang merupakan salah satu implementasi dari tujuan pendidikan tinggi Muhammadiyah yaitu terbinanya keislaman dan kemuhammadiyahan yang mencerdaskan dan mencerahkan bagi seluruh civitas akademika.

Tujuan: Untuk menganalisis pengaruh Program Kuliah Pas Sepuluh Menit (Kupas Baik) Mahasiswa Terhadap Penerapan Pelayanan Islami Pada Pasien Rawat Inap Di RSUD Nene Mallomo Kabupaten Sidrap

Metode: Penelitian pre-experimental design dengan desain one-shot case study. Populasi penelitian 105 orang . Sampel berjumlah 93 orang. Tekhnik Pengambilan Sampel menggunakan teknik purposive sampling. Instrumen penelitian menggunakan kuisioner. Teknik analisa data menggunakan One- Way Anova.

Hasil: Nilai $F$ hitung sebesar 35,76 dan nilai $F$ tabel yaitu 3,10 sehingga nilai $F$ hitung $<F$ tabel $(35,76<3,10)$ artinya ada pengaruh linear kupas baik terhadap pelayanan Islami.

Simpulan: Diharapkan penerapan model pelayanan yang islami sebagai salah satu alternative untuk pengobatan pada pasien serta memberikan asuhan medik dan keperawatan yang dibingkai dengan kaidah - kaidah islam dengan pendekaan holistic dalam bentuk pelayanan biopsiko-sosial-kultural maupun spiritual

\section{Kata Kunci: Kupas Baik; Pelayanan Islami; Pasien; Rawat inap}

\section{PENDAHULUAN}

Kegiatan Kuliah Pas Sepuluh Menit Belajar AlIslam dan Kemuhammadiyahan (KUPAS BAIK) adalah program kegaiatan yang dilakukan oleh Kantor Urusan Internasional , Kerjasama dan
Pengembangan Al- Islam \& Kemuhammadiyahan yang merupakan salah satu implementasi dari tujuan pendidikan tinggi Muhammadiyah yaitu terbinanya keislaman dan kemuhammadiyahan yang mencerdaskan dan mencerahkan bagi seluruh civitas 
Pengaruh kupas baik mahasiswa terhadap penerapan pelayanan Islami pada pasien rawat inap

akademik

(Sekolah

Tinggi

Kesehatan Muhammadiyah Sidrap, 2019). Sebagai organisasi Islam, Muhammadiyah yang berdiri sejak tahun $1912 \mathrm{M}$, dan berusaha mengajak umat Islam untuk selalu memurnikan amalan ajaran Islam mengikuti Al Qur'an dan tuntunan Nabiyullah Muhammad SAW dalam gerakan dakwah "amar ma'ruf nahi munkar", (Mu'in, 2017; Purnomo, 2014; Harianto, 2018).

Seseorang pasien yang telah berusaha maksimal untuk mencari kesembuhan dari penderitaan, stres berat atau penyakit kronis, namun tidak memperoleh hasil optimal dari usahanya namun tetap semangat dengan dorongan spiritual sesuai filosofi tentang sehat atau sakit, makna hidup terkait penderitaan yang dialami. Pasien akan mencari kenyamanan dan kekuatan dari Tuhan. Mereka yang memiliki pengahayatan nilai spiritual tinggi, dapat menciptakan kondisi berpersepsi yang baik terhadap stres dan berespon lebih positif, sehingga immunitas tubuh meningkat dan proses penyembuhan lebih cepat. Pada dasarnya Nilai spiritualitas dapat dikuatkan sejak awal, dan tidak menunggu sampai mengalami penderitaan yang lebih buruk (Hamid, \& Hamid, 2015; Yusuf, Nihayati, Iswari, \& Okviansanti, 2016).

Hasil Penelitian sebelumnya di RSUD Meuraxa Kota Banda Aceh tentang pengaruh pelayanan Islami terhadap kepuasan pasien menunjukkan bahwa pelayanan Islami memiliki pengaruh yang signifikan terhadap kepuasan pasien, Aadapun tingkat persentase pengaruhnya adalah $65.0 \%$ (Laena, 2019; Fatimah, 2019).

Seseorang pasien yang telah berusaha maksimal untuk mencari kesembuhan dari penderitaan, stres berat atau penyakit kronis, namun tidak memperoleh hasil optimal dari usahanya namun tetap semangat dengan dorongan spiritual sesuai filosofi tentang sehat atau sakit, makna hidup terkait penderitaan yang dialami. Pasien akan mencari kenyamanan dan kekuatan dari Tuhan. Mereka yang memiliki pengahayatan nilai spiritual tinggi, dapat menciptakan kondisi berpersepsi yang baik terhadap stres dan berespon lebih positif, sehingga immunitas tubuh meningkat dan proses penyembuhan lebih cepat. Pada dasarnya Nilai spiritualitas dapat dikuatkan sejak awal, dan tidak menunggu sampai mengalami penderitaan yang lebih buruk (Hamid, \&
Hamid, 2015; Yusuf, Nihayati, Iswari, \& Okviansanti, 2016).

Pasien yang mengidap penyakit berat mengalami berbagai kecemasan, ketakutan, demikian juga pasien yang akan menghadapi operasi dan pascaoperasi, pasien yang menghadapi saat kritis seperti menghadapi kematian, sakaratul maut (naza', dying), sudah bukan ranah persoalan perawatan medis semata, melainkan sangat memerlukan pendampingan, layanan, dan bantuan spiritual (Aryanto, 2017).

Salah satu kebutuhan mendesak bagi pasien rawat inap di rumah sakit adalah perlunya layanan spiritual untuk memenuhi kebutuhan spiritual pasien. Sedangkan kebutuhan spiritual pasien merupakan kebutuhan dasar dan mutlak yang tidak dapat digantikan oleh asuhan dan layanan apapun. Karena itu pemberian bantuan dan layanan spiritual ini tidak akan cukup jika hanya diberikan melalui asuhan keperawatan medis melainkan harus disampaikan melalui layanan secara terfokus, lebih spesifik, diberikan oleh seorang profesional, dan berorientasi pada situasi kebutuhan spiritual pasien, tersusun dalam sebuah program secara mandiri, terencana, dan sistematis (Arifin, 2012; Abdurrahmat, 2015).

RSUD Nene Mallomo merupakan salah satu istansi pemerintah yang melayani masyarakat di bidang kesehatan. Pelayanan kesehatan merupakan setiap upaya yang diselenggarakan sendiri atau bersama-sama dalam suatu organisasi untuk memelihara dan meningkatkan kesehatan, mencegah dan menyembuhkan penyakit, serta memulihkan kesehatan perseorangan, keluarga, kelompok dan masyarakat (Hasnani, 2019; Andrianto, \& Nursikuwagus, 2017).

Melalui observasi yang sederhana ditemukan bahwa pelayanan yang dilakukan RSUD Nene Mallomo belum menerapkan konsep Islami dan pendekatan spiritual dalam mengobati pasien, Hal ini dibuktikan sebagian besar perawat belum menambahkan unsur spiritual dalam pelaksanaan tindakan asuhan keperawatan, terutama pada pasien dengan kebutuhan spiritual yang tinggi , misalnya pada pasien akut dan dengan keadaan terminal. Namun tidak bisa dipungkiri bahwa pelayanan yang islami dengan mengedepankan kepuasa pasien merupakan salah satu bentuk pengobatan pada pasien. Tindak lanjutnya mahasiswa STIKES Muhammadiyah Sidrap yang melakukan praktik klinik

Nurjanna, Wilda Rezki Pratiwi* Program Studi DIll Kebidanan STIKES Muhammadiyah Sidrap.

*Email: wildapratiwi06@gmail.com 
Pengaruh kupas baik mahasiswa terhadap penerapan pelayanan Islami pada pasien rawat inap

di Rumah Sakit Umum Daerah mengupayakan adanya pendampingan, layanan, dan bantuan spiritual sebagai bentuk pelayanan yang islami sehinggah ada upaya untuk peningkatan mutu pelayanan kesehatan.

\section{METODE PENELITIAN}

Penelitian pre-experimental dengan desain oneshot case study. Penelitian ini dilaksanakan pada bulan Juni hingga Juli 2020. Populasi penelitian adalah 105 orang. Sampel berjumlah 93 orang. Teknik Pengambilan Sampel menggunakan teknik purposive sampling Mahasiswa yang menjadi responden diberikan perlakuan mengikuti program kupas baik setiap $3 \times$ seminggu selama 1 bulan sebelum praktik klinik di Rumah Sakit dengan menggunakan metode ceramah yang dibawakan oleh pemateri yang ahli dalam bidang keagamaan dengan materi penerapan pelayanan islami dalam asuhan kebidanan.

Pengumpulan data dilakukan dengan menggunakan kuesioner yang terdiri dari data karakteristik responden terdiri dari umur, jurusan, jenis kelamin. Selain itu juga terdapat kuesioner penerapan pelayanan islami yang terdiri dari 15 item pertanyaan. Teknik analisa data menggunakan OneWay Anova untuk melihat pengaruh kupas baik terhadap pelayanan islami. Responden menerapkan pelayanan islami jika hasil kuesioner $\geq 85$ dan tidak menerapkan $\leq 85$ dan keaktifan mengikuti kupas baik selama pelaksanaan kupas baik > $80 \%$ dikatakan aktif dan jika < 80\% tidak aktif.

HASIL

Tabel 1. Karakteristik Demografi Responden $\mathrm{N}=93$

\begin{tabular}{|c|c|c|c|c|c|c|c|}
\hline \multirow[t]{3}{*}{ Demografi } & \multicolumn{4}{|c|}{ Pelayanan Islami } & \multirow[b]{3}{*}{ Mean \pm SD } & \multirow[b]{3}{*}{$p$-value } & \multirow[b]{3}{*}{ OR } \\
\hline & \multicolumn{2}{|c|}{ Menerapkan } & \multicolumn{2}{|c|}{$\begin{array}{l}\text { Tidak } \\
\text { Menerapkan }\end{array}$} & & & \\
\hline & $n$ & $\%$ & $\mathrm{n}$ & $\%$ & & & \\
\hline Usia (Tahun)(Rentang: 19-22) & & & & & $20.03 \pm 0.74$ & 0.000 & 0.310 \\
\hline \multicolumn{8}{|l|}{ Jurusan } \\
\hline Kebidanan & 54 & 58.1 & 1 & 1.1 & & & \\
\hline Keperawatan & 35 & 37.6 & 3 & 3.2 & & & \\
\hline \multicolumn{8}{|l|}{ Semester } \\
\hline Dua (II) & 43 & 46.2 & 2 & 2.15 & & 0.000 & 0.033 \\
\hline Empat (IV) & 45 & 48.3 & 3 & 3.22 & & & \\
\hline \multicolumn{8}{|l|}{ Jenis Kelamin } \\
\hline Perempuan & 49 & 52.7 & 1 & 1.1 & & 0.468 & 0.860 \\
\hline Laki-Laki & 40 & 43.0 & 3 & 3.2 & & & \\
\hline
\end{tabular}

Berdasarkan tabel 1 didapatkan bahwa berdasarkan nilai $p$ value variabel yang berpengaruh terhadap penerapan pelayanan islami adalah umur dan semester mahasiswa sedangkan berdasarkan nilai OR variabel yang lebih berpengaruh adalah jenis kelamin sekitar 0,86 ( 86\%).

Tabel 2 Analisis Uji Anova

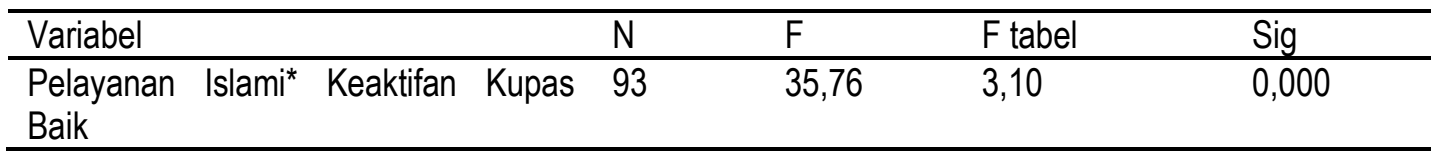

Nurjanna, Wilda Rezki Pratiwi* Program Studi DIIl Kebidanan STIKES Muhammadiyah Sidrap.

*Email: wildapratiwi06@gmail.com 
Pengaruh kupas baik mahasiswa terhadap penerapan pelayanan Islami pada pasien rawat inap

Berdasarkan tabel 2 didapatkan hasil bahwa Nilai $F$ hitung sebesar 35,76 dan nilai $F$ tabel yaitu 3,10 sehingga nilai $F$ hitung $<\mathrm{F}$ tabel $(35,76<3,10)$ artinya ada pengaruh linear kupas baik terhadap pelayanan islami.

Tabel 3. Uji Korelasi

\begin{tabular}{llll}
\hline Variabel & $\mathrm{N}$ & Correlation Coefficient & Sig.(2-tailed) \\
\hline Pelayanan Islami & 93 & 1,000 & 0,000 \\
Keaktifan Kupas Baik & 93 & 0,989 & 0,000 \\
\hline
\end{tabular}

Berdasarkan tabel 3 didapatkan hasil uji korelasi antara variabel yang diteliti nilai sig (2- tailed) 0,000 yang artinya terdapat pengaruh kupas baik dengan pelayanan islami.

Tabel 4. Uji Regresi Linear

\begin{tabular}{lllllll}
\hline Variabel & & $\mathrm{R}$ & $\mathrm{R}$ Square & $\begin{array}{l}\text { Adjusted } \\
\text { Square }\end{array}$ & $\mathrm{R}$ & $\begin{array}{l}\text { Std. Error of } \\
\text { the Estimate }\end{array}$ \\
\hline $\begin{array}{l}\text { Pelayanan } \\
\text { Baik }\end{array}$ & Islami* & Keaktifan Kupas & 0,921 & 0,848 & 0,846 & 1,478
\end{tabular}

Berdasarkan tabel 4 uji regresi linear. Nilai korelasi atau hubungan ${ }^{\circledR}$ sebesar 0.921 dan $\mathrm{R} 2$ sebesar 0.848 maka dapat disimpulkan bahwa ada pengaruh variabel Kupas Baik terhadap Pelayanan Islami sebesar $84.8 \%$ sedangkan $15.2 \%$ dipengaruhi oleh variabel lain dan tidak diteliti.

\section{PEMBAHASAN}

Berdasarkan hasil analisis One - Way Anova test pada Nilai $F$ hitung sebesar 35,76 dan nilai $F$ tabel yaitu 3,10 sehingga nilai $F$ hitung $<F$ tabel $(35,76<$ $3,10)$ artinya ada pengaruh linear kupas baik terhadap pelayanan islami. Sedangkan Berdasarkan tabel 5.3 didapatkan hasil uji korelasi antara variabel yang diteliti nilai sig (2- tailed) 0,000 yang artinya terdapat pengaruh kupas baik dengan pelayanan islami.

Hasil penelitian dari beberapa sumber menjelaskan bahwa 91\% pasien mencari bantuan spiritual dan kerohanian untuk membantu proses penyembuhannya, dan lebih dari $64 \%$ pasien mengatakan bahwa dokter sebaiknya memberikan terapi psiko religus dan doa (Riyadi, 2012). Sedangkan menurut hasil penelitian tentang peran bimbingan rohani terhadap pasien Rumah Sakit Umum Muhammadiyah Sumatra pada umunya adalah bimbingan rohani yang memiliki fungsi positif bagi pasien yang bekerja dan membantu menangani masalah yang dialami oleh pasien dengan tekhnik bimbingan langsung dan terbuka baik kepada pasien dan keluarga pasien sehingga termotivasi dan merasa nyaman (Panjaitan, 2017).

Pada peneliian yang lainnya didapatkan pengaruh secara signifikan antara pelayanan islami terhadap kepuasan pasien dimana nilai Koefesien $\mathrm{R}$ Square yang diperoleh sebesar 0,650 artinya besar pengaruh pelayanan islam terhadap kepuasan pasien dirumah sakit sebesar 65\% (Laena, 2019). Hasil penelitian yang dilakukan di Rumah Sakit Ibnu Sina Makassar didapatkan nilai $r$ sebesar 0,713 menunjukan bahwa ada hubungan antara pelayanan dengan prinsip syariah memberikan pengaruh terhadap kepuasan pasien sebesar 50,8\% dan 49,2\% dipengaruhi oleh faktor lain (Hafid, 2016).

Pelayanan islami memiliki konsep atau krakteristik utama dalam pelayanan yang islami, yaitu : Rabbaniyah, akhlaqiyah, waqi'yah dan insaniyah. Karakteristik tersebut yang membedakan antara pelayanan rumah sakit yang berlandaskan islam dengan rumah sakit non islam (Sunawi, 2012; Sari, Abdurrouf, \& Rismawati, 2018). Kupas baik yang merupakan program kegiatan yang dikembangkan di STIKES Muhammadiyah Sidrap dengan tujuan terbinanya keislaman kemuhammadiyahan bagi seluruh civitas akademika (Sekolah Tinggi Kesehatan Muhammadiyah Sidrap, 2019). Kegiatan ini rutin dilakukan setiap hari dilingkungan STIKES Muhammadiyah Sidrap. Kupas baik sama halnya dengan ceramah agama, dakwah dan bimbingan keagamaan yang dikhususkan kepada mahasiswa

Nurjanna, Wilda Rezki Pratiwi* Program Studi DIll Kebidanan STIKES Muhammadiyah Sidrap.

*Email: wildapratiwi06@gmail.com 
Pengaruh kupas baik mahasiswa terhadap penerapan pelayanan Islami pada pasien rawat inap

sebagai bentuk penyelenggaraan pendidikan Muhammadiyah yaitu manusia muslim yang berakhlaq mulia, cerdas dan berguna bagi umat dan bangsa. Dalam pendidikan Muhammadiyah berkomitmen untuk mencetak elit muslim terdidik, diharapkan mahasiswa dapat tersentuh untuk menerapkan amal - amalan yang diajarkan, membentuk manusa muslim yang berakhlaqul karimah dan siap mengabdi demi kepentingan agama islam dalam masyarakat (Faridi, 2010). Secara Umum mahasiswa menyetujui adanya AlIslam Kemuhammadiyahan (AIK) yang dapat tercermin dari persepsi mahasiswa bahwa AlK dipandang sangat perlu diberikan kapada mahasiswa dikarenakan STIKES Muhammadiyah Sidrap memiliki prioritas utama yang ingin dicapai yaitu unggul, professional dan beraklaqul karimah. Berdasarkan tabel uji regresi linear. Nilai korelasi atau hubungan $\mathrm{R}$ sebesar 0.921 dan $\mathrm{R}$ Square sebesar 0.848 maka dapat disimpulkan bahwa ada pengaruh variabel Kupas Baik terhadap pelayanan islami sebesar $84.8 \%$ sedangkan $15.2 \%$ dipengaruhi oleh variabel lain dan tidak diteliti.

Menurut peneliti faktor yang lain yang memungkinkan untuk tidak menerapkan pelayanan islami adalah kurangnya kesadaran mahasiswa untuk menjalankan fungsi sebagai khalifah dalam memberikan asuhan medik pada pasien selain dari pada itu faktor lain yang mendasari adalah kurangnya sikap mahasiswa untuk meningkatkan mutu pelayanan kesehatan yang berorientasi pada asuhan spiritual dalam memberikan pertolongan kepada pasien.

Berdasarkan hal - hal diatas maka peneliti dapat menyimpulkan bahwa pelayanan yang islami berpengaruh secara tidak langsung terhadap kepuasaan dan kepercayaan pasien. Berarti semakin baik kualitas pelayanan islami yang diberikan maka semakin meningkat kepuasaan pasien yang diberikan kepada mahasiswa yang menerapkan media kupas baik sebagai pelayanan islami yang diaplikasikan kepada pasien dalam proses penyembuhan selama perawatan di Rumah Sakit. Pasien yang puas terhadap pelayanan yang diberikan oleh suatu rumah sakit menjadikannya loyal terhadap rumah sakit tersebut, hal ini dibuktikan dengan pasien akan menggunakan kembali apabila mengalami sakit yang sama atau karena sakit yang lain dan akan merekomendasikan kepada orang lain untuk menggunakan rumah sakit tersebut, loyalitas pasien salah satunya dipengaruhi oleh pelayanan keperawatan yang baik (Chahal, 2008; Fajar, 2016).

\section{SIMPULAN}

Hasil uji dan analisa statistik didapatkan adanya pengaruh kupas baik yang diberikan mahasiswa kepada pasien yang dirawat di rumah sakit.

\section{SARAN}

Bagi Manajemen pihak rumah sakit supaya dapat menerapkan model pelayanan yang islami sebagai salah satu alternative untuk pengobatan pada pasien serta memberikan asuhan medik dan keperawatan yang dibingkai dengan kaidah - kaidah islam dengan pendekatan holistic dalam bentuk pelayanan biopsiko-sosial-kultural maupun spiritual. Perlunya penelitian berkelanjutan untuk pengembangan program lain di bidang Al-Islam dan kemuhammadiyahan sebagai pendidikan karakter pada setiap pelayanan kesehatan yang akan diterapkan bagi mahasiswa bukan hanya pada saat masih dalam proses pembelajaran namun pada saat mereka berada di dunia kerja.

\section{DAFTAR PUSTAKA}

Abdurrahmat, F. (2015). Manajemen Sumber Daya Manusia, Bandung Rineka.

Andrianto, P., \& Nursikuwagus, A. (2017). Sistem Informasi Pelayanan Kesehatan Berbasis Web di Puskesmas. In Seminar Nasional Komputer dan Informatika (p. 6).

Arifin, I. (2012). Bimbingan dan Konseling Islam untuk Pasien Rawat Inap di Rumah Sakit. 6 No 1 Juni.

Aryanto, I. (2017). Pelaksanaan Bimbingan Perawatan Rohani Islam (Warois) Untuk Memenuhi Kebutuhan Spiritual Pasien: Penelitian Di Rsu Cibabat, JI Jend. H. Amir Machmud No. 140 Kota Cimahi (Doctoral dissertation, UIN Sunan Gunung Djati Bandung).

Chahal, H. (2008). Redicting Patient Loyalty and Service Quality Relationship: A Case Study of Civil Hospital. Vol 12 No.4.

Nurjanna, Wilda Rezki Pratiwi* Program Studi DIll Kebidanan STIKES Muhammadiyah Sidrap.

*Email: wildapratiwi06@gmail.com 
Pengaruh kupas baik mahasiswa terhadap penerapan pelayanan Islami pada pasien rawat inap

Fajar, M. I. (2016). Pengaruh Kualitas Pelayanan Dan Kepuasan Pasien Terhadap Loyalitas Pasien Rawat Jalan Dan Rawat Inap Di Rumah Sakit Embung Fatimah Batam. Vol. 3, No 2.

Faridi, F. (2010). Persepsi Mahasiswa Terhadap Mata Kuliah Al Islam Dan Kemuhammadiyahan (AIK): Internalisasi Nilai-nilai Aik Bagi Mahasiswa. Progresiva, 4(1), 220737.

Fatimah, N. (2019). Urgensi Layanan Unit Pelayanan Islami terhadap Pasien Operasi pada RSUD Meuraxa Kota Banda Aceh (Doctoral dissertation, UIN Ar-Raniry Banda Aceh).

Hafid, H. P. (2016). Pengaruh Pelayanan dengan Prinsip-prinsip Syariah Terhadap Kepuasan Pasien (Kasus pada RS Ibnu Sina Makassar) (Doctoral dissertation, Universitas Islam Negeri Alauddin Makassar).

Hamid, A. Y., \& Hamid, S. (2015). Aspek spiritual dalam keperawatan. Widya Medika: Jakarta.

Harianto, E. (2018). Empat Pilar Pendidikan Muhammadiyah. Prosiding Konferensi Nasional Ke-7 Asosiasi Program Pascasarjana Perguruan Tinggi Muhammadiyah Aisyiyah (APPPTMA).

Hasnani. N. (2019). Pelayanan Kesehatan di RSUD Nene Mallomo. Sidrap.

Laena, H. (2019). Kinerja Unit Pelayanan Islami Terhadap Bimbingan Ibadah Pada Pasien Rawat Inap RSUD Meuraxa Kota Banda Aceh (Doctoral dissertation, UIN Ar-Raniry Banda Aceh).

Mu'in, J. A. (2017). Metode islam berkemajuan dalam meningkatkan produktivitas amal usaha muhammadiyah. Sinar sang surya: Jurnal Pusat Pengabdian Kepada Masyarakat, 1(1), 49-60.
Panjaitan, N. (2017). Bentuk Bimbingan Rohani dalam Mengatasi Stres pada Pasien Rumah Sakit Umum Muhammadiyah Sumatra Utara. Sumatra Utara: Fakultas Dakwah dan Komunikasi Universitas Islam Negeri.

Purnomo, H. (2014). Sejarah Dan Perkembangan Muhammadiyah Cabang Kota Kudus Tahun 1920-2013 (Doctoral dissertation, Universitas Muhammadiyah Surakarta).

Riyadi, A. (2012). Dakwah terhadap Pasien (Telaah terhadap Model Dakwah melalui Sistem Layanan Bimbingan Rohani Islam di Rumah Sakit). Dalam Konseling Religi: Jurnal Bimbingan Konseling Islam, 3(2).

Sari, D. W. P., Abdurrouf, M., \& Rismawati, R. (2018). Relationship between sharia-based nursing services and patient loyality at islamic hospital. Nurscope: Jurnal Penelitian dan Pemikiran IImiah Keperawatan, 4(2), 109-117.

Sekolah Tinggi Kesehatan Muhammadiyah Sidrap (2019). Pedoman Al- Islam Kemuhammadiyahan. Sidrap. Diakses dari: http://stkmsidrap2009.ac.id/downlot.php?file=Stat uta\%20STKMS\%202015\%20asli.pdf

Sunawi, S. (2012). Konsep Pelayanan Kesehatan Islami Di Rumah Sakit (Tinjauan Aplikasi Di Rumah Sakit Islam Surakarta (Doctoral dissertation, Universitas Muhammadiyah Surakrta).

Yusuf, A., Nihayati, H. E., Iswari, M. F., \& Okviansanti, F. (2016). Kebutuhan spiritual: konsep dan aplikasi dalam asuhan keperawatan. Buku Referensi, 1-316. 